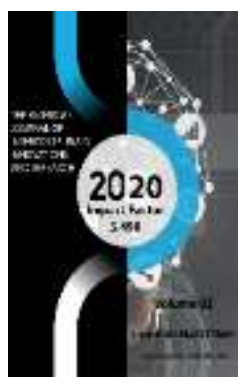

\title{
Socio-Geographical Aspects Of The Culture Of Nature Use Of The Population Of The Fergana Valley
}

\author{
Nargizakhon Komilova \\ PhD, Senior Teacher Fergana State University, Faculty Of Natural Sciences, Department Of \\ Geography, Uzbekistan
}

\begin{abstract}
Journal Website: http://usajournalshub.c om/index,php/tajiir

Copyright: Original content from this work may be used under the terms of the creative commons attributes 4.0 licence.
\end{abstract}

\section{ABSTRACT}

The growth of the world's population and the accelerated development of economic sectors are causing the expansion of the use of natural resources and an increase in anthropogenic pressure on them. This situation causes social and environmental problems in regions with intensively developed sectors of the economy and high population density.

\section{KEYWORDS}

Ethno-demography, ethno-ecosystems, G. Konklin, Johannesburg

\section{INTRODUCTION}

A number of UN conferences (Rio de Janeiro, 1992; Johannesburg, 2002, New York, 2015) pay special attention to ensuring the sustainable development of such areas, the principles of protecting humanity from future socioecological disasters and the transition to sustainable development of these regions is "recognition of traditional knowledge and values, ways of using the resources of the indigenous population" [1]. In the Republic of Uzbekistan, special attention is paid to the use of available natural resources on a scientific basis, the distribution of industries and populations that correspond to natural conditions, traditions of each region and contribute to their effective use for sustainable 
socio-economic development. The "Strategy of actions for the further development of the Republic of Uzbekistan for 2017-2021" outlines important tasks to "prevent environmental problems that damage the environment, health and gene pool of the population." In this regard, scientific research aimed at the rational use of natural resources and the prevention of social and environmental problems, based on the experience of the local population, are of great importance [2].

\section{THE MAIN RESULTS AND FINDINGS}

Today the situation has changed radically. In solving environmental problems, along with modern innovative approaches about the importance of an ethno-ecological approach based on the traditions of natural resource use of the local population, the President of our country Sh. M. Mirziyoev writes: "I am convinced that, relying on the centuries-old traditions of our peoples for respect for nature and the joint use of common water resources, we will be able to achieve truly breakthrough results." In particular, in the UN Sustainable Development Program until 2030, one of the 17 goals is aimed at solving the problems of "protecting and restoring terrestrial ecosystems, their rational use, sustainable forest management, combating desertification, stopping land degradation and preventing the depletion of biological diversity". It is especially important to solve these problems in those regions that have high demographic loads and anthropogenic pressure on nature [3,4].

When determining the main object of research in the scientific direction of ethnoecology, two approaches are observed; V.I.Kozlov (1983), I.Yu. Gladkiy (2003), A.N. Yamskov (2013) ethnoecology as a scientific discipline "located at the junction of ethnography and human ecology (social ecology), and having zones of overlap with ethnic geography , ethnodemography and ethnic anthropology, studying the features of the traditional life support system of ethnic groups and ethnic groups in general, the specifics of the use of the natural environment by ethnic groups and their impact on this environment, the traditions of rational nature management, as well as the patterns of formation and activity of ethnoecosystems. The term ethnoecology, who introduced the term ethnoecology (from the Greek ethnos - people, oikos - house, dwelling, logos - word, teaching), G. Konklin (1954), such scientists as I. I. Krupnik (1989), R. F. Itts (1991), I. Zhabborov (2008), as well as R. Ballieva (2003) consider ethnoecology as a scientific direction that studies in a broad sense the relationship of various ethnic groups and nature, the traditional culture of its use and has a deep interdisciplinary basis.

The abrupt change or oblivion of the ethnoecological culture used by the local population in all historical periods caused negative ecological consequences, which can be determined with the help of a historical excursion. As a result of the study, it was shown that due to neglect and neglect, the cultures of land and water use used by the local population, especially in areas with a dry climate, both in ancient periods (Babylonian catastrophe), and in our time (the problem of the Aral Sea) can lead to negative environmental consequences. 
The reason is that this research is both natural and social in nature. Most of the problems awaiting their solution are of a natural and ecological character, and the solution of sociohistorical issues plays an important role in their solution. Therefore, in the research work, special attention is paid to the sociogeographical and ecosystem approaches, which have incorporated complex views.

To maintain the ecological balance in the world, along with innovative views, a historical approach is also required. The principles, types and forms of the use of nature by human society under the influence of various factors change synchronously over the periods. This situation can be even more clearly manifested in the process of land and water use, which was substantiated by V.A.Pulyarkin on the example of the countries of the world. After analyzing, relying on these methodological foundations, Yu. I. Akmadaliev proposed to distinguish three types of territorial organization of the use of natural resources. Based on the goals of nature management, these species are conventionally named natural-historical, commodity-target and program-target.

Nature management, which existed in the Fergana Valley until the end of the 19th and beginning of the 2oth century and based on the natural capabilities of the territory, we refer to the natural-historical type, since during this period the organizational aspects of this issue were not sufficiently developed. This type of nature management takes into account the features of the relief, climate, soil, the closed place of the valley, as well as national and ethnic characteristics, skills, experience and customs of the population. This species is usually formed over a long historical time, the skills, qualifications and customs accumulated in it are based on harmonious, proportionate relationships with nature. Therefore, if viewed from an ecological point of view, this species is the most durable, and for this purpose it deserves study [5].

With the improvement of relations in the "nature-population-economy" system, the place of the first type of nature management is taken by the commodity-target type. In this form, along with the natural capabilities of the region, subjective factors are also taken into account (for example, an increase in the need for commercial crops or the arrival of foreign ethnic groups in the landscape). As a result, the features of the natural landscape of the territory change, the achievements of scientific and technological development are widely used. Although the economic efficiency is becoming high, as a result, the basis for the emergence of geo-ecological problems is being prepared. This species existed in the Fergana Valley from 1876 to 1991.

The third type of relationship in the "naturepopulation-economy" system, i.e. "Programtarget type" based on the principles of sustainable development of nature management is inherent in highly developed, independent states. The transition to this species in the Fergana Valley began after our independence.

Taking into account the interdisciplinary nature of ethnoecological culture in its systemic study, one can use the "chamomile" model method proposed by V.N Kalutskov. This model, ensuring the complexity, integrity, unity in the study of the object, pays attention to the study not of individual components of the ethnolandscape, but to the study of internal (system) 
connections between them. Therefore, when studying the territorial aspects of the ethnoecological culture of the population of the Fergana Valley, the indicators are summarized in 3 blocks ("nature-population-economy"), which ensure the above connection and integrity.

In the first block, such indicators as the shape of the relief, the type of soil and the amount of precipitation associated with the height above sea level were studied, which are the reason for the appearance of parts that have the same environmental conditions and similar methods, skills, and experience in nature management.

In the second block of ethnic indicators, the share of the main ethnic group in the region was studied. Ethnocultural centers in the region were identified, performing the function of a "central place", "ethnic nucleus" or "information center", incorporating the population of a certain territory performing political, administrative, religious, and economic tasks. Professions that have formed qualifications and skills of the main ethnic group must be taken into account, in the third block, economic indicators are taken into account as the main irrigation network, the share of irrigated land, the structure of land and sown areas. The importance of these factors in the region-forming process and the provision of ethno-ecological balance in the territories with irrigated agriculture have been scientifically substantiated [6].
By means of quantitative assessments of landscape, ethnic and economic indicators in the Fergana Valley, 4 ethno-landscape regions and 17 ethno-ecological regions were identified.

The first ethno-landscape region - occupies the extreme part of the fan and the desert territories of central Fergana. In the region, such negative changes in the soil and ecological state are observed, such as groundwater mineralization, soil salinization, migration of sand dunes. Therefore, a set of measures to eliminate these negative consequences on the territory is the basis for land use. Land categories are mainly used as reserve land, as well as spring and autumn pastures. Bushes such as saxaul, turangil and jilan-jiydah were planted in this area against the sand dunes. The main parts of the cultivated area were cultivated with sol-resistant species of sorghum and three types of rice, white rice, barley and red rice, which, when grown, cultivate salted lands.

The second ethno-landscape region occupies the central part of the fan lobes; the main part of the irrigated land is located in this region. The crop structure includes cereals, oilseeds, fiber and forage crops. Selected from lowwater, early-maturing varieties of grain crops, such as bean, millet, rye, winter wheat. Sesame, cotton, flax, rapeseed, safflower, poppy, sunflower, cannabis, fodder, corn, alfalfa and barley occupy a large area of oil crops. 


\section{Picture 1}

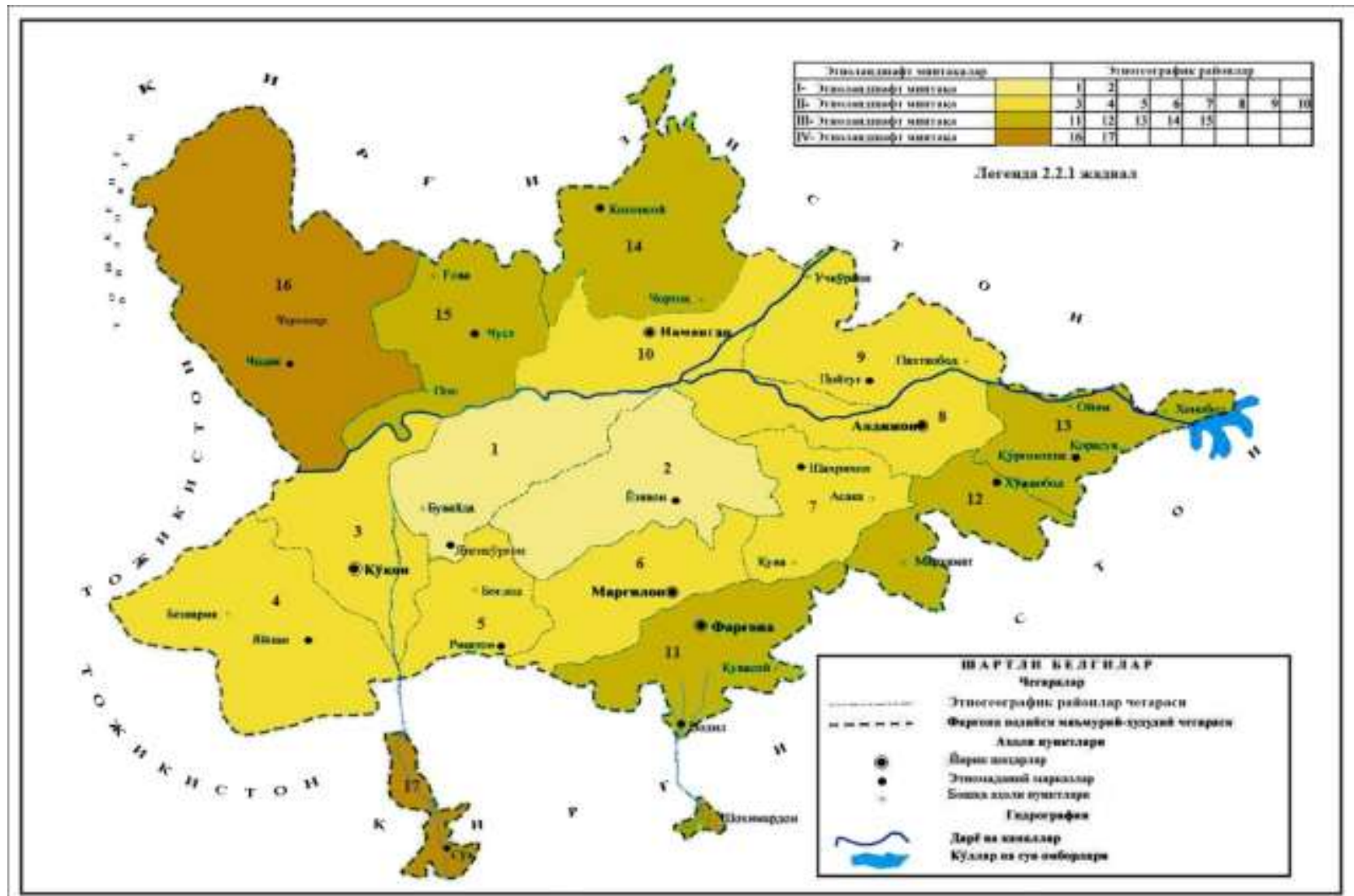

2.2.1-РАСМ, ФАРГОНА ВОДИЙСИНИНГ ЭТНОГЕОГРАФИК РАЙОНЛАРИ

The third ethnolandscape region forms the upper parts of the alluvial cone and inter-ridge fallouts. In the structure of the category of land, most of it is occupied by land occupied by irrigation facilities (water distribution system). The region is of particular importance in agriculture as it specializes in orchards and vineyards. For each region, "specialized" plant and tree species were identified. In the regions, about 70 species of trees and crops have been identified as Kuva pomegranate, Namangan apple, Kokand cherry, Andijan pear, Margilan grape, Chusta pear, Isfara, Rishtan apricot,
Kuvasai peach, Yarmazar nut, Vuadil plane tree, Sokhkan seafood, Khaidyavan melon, Altarik cucumber, Buvaida rice, Kakirsky pepper, which specialize not only in the appropriate natural conditions, but also in the skills and abilities of the local population.

The fourth ethno-landscape region includes Alay, Turkistan, Fergana, Kuram, Chatkal ridges and hills, and steep rock formations alternate with deep valleys. The territory is mainly concentrated "reserve", dedicated to the shrine guarding the catchment of the rivers. In 
the valleys, agriculture is partially used, while other areas are reserved for cattle breeding and mountain gardening. To prevent water erosion, the river valleys are planted with rice and other root crops such as winter wheat, potatoes and carrots.

The historical and local methods used in agriculture, such as crop rotation, the use of irrigated land for the use of virgin soil and fertilizers, are studied. To prevent the depletion of arable land and the decline in soil fertility, such sayings were used: "from the land, how many carts you will collect alfalfa and how much you must lay out manure".

Studying the territorial aspects of the rational and efficient use of water resources in the Fergana Valley. According to some scientists, the next distribution of water in irrigation ditches was determined by drawing lots, by the will of elders and mirabs, and even by buying and bribing. However, our cartographic and field studies carried out in the Rishtan irrigation ditch showed that the distribution of water in the irrigation ditch is an example of high ethnoecological culture, taking into account the peculiarities of the soil-ecological state of the territory and the needs of water in crops. The advantages of combining irrigation systems with administration in the field of water saving and fair distribution were studied at the Shakhrikhansai premiere.

The existence of 4 types of settlement of settlements associated with the production and irrigation system in the valley, which are important in the ethno-ecological aspect, is shown. The first type of settlements, in which animal husbandry, gardening and crafts are developed, are located between two landscape regions (mountains and foothills) and have the form of an ancient "mound", these include Isfara, Sokh, Kuva, Mingtepa, Osh, Kasan and others [7 ].

The second type of settlements is located in the form of a ribbon along the irrigation system (river, springs, canal), which is observed in Namangan. The advantages of this species from an ecological point of view are that there is no need to change the regime of rivers and springs, to build large canals and reservoirs.

The third type of location of settlements ensures the distribution in equal quantities and at equal distances of land resources, which are the main means of production for each village located in the fan. This view is shown on the example of villages located in Sokh. An important aspect of such placement in the ecological aspect is the existence of the possibility of using a single mechanism for managing crop rotation and crop selection in villages.

The fourth type of villages is formed mainly under the influence of economic indicators around large trade and handicraft centers; they are explained by the example of the city of Margilan and the villages located around it.

\section{CONCLUSION}

Recommendations on the use of samples of ethno-ecological culture for sustainable development of the Fergana Valley were developed in the following 5 directions considered in the study: 1. Distribution of territories, agricultural lands and structures of cultivated areas in accordance with the landscape type and labor skills of the population. 2. When organizing the economical 
use of water resources and water management, take into account the historical and geographical experience. 3. Compliance with the requirements of ecological architecture and ecological design in the territorial distribution of settlements. 4 . When organizing nature management, use the humanitarian and geographical knowledge of the local population (ecotoponymy, sacred place and worship). 5. Application of samples of ethno-ecological culture in education and upbringing.

The categories of land, types of land, main crops and trees for each ethno-landscape region and ethno-ecological region under traditional land use in the Ferghana valley from the end of the XIX century to the beginning of the $X X$ century are determined. It is advisable to use historical and local methods of crop rotation, the use of land for fallow, as well as fertilizers. In the valley, a culture of "alternate" distribution of water in irrigation ditches has formed, which saves water resources, does not change the regime and direction of river flow, and takes into account soil maturation and its need for water. As a result of the coordination of the irrigation system with the method of administrative management of the region, a basin management system was created that allows saving and fair distribution of water resources.

\section{REFERENCES}

1. Agenda for Sustainable Development until 2030 |l Electronic access: http://www.uz/undp/org/content/uzbekist an.ru

2. Decree of the President of the Republic of Uzbekistan No. UP-4947 dated February 7, 2017 "On the Strategy of Actions for the
Further Development of the Republic of Uzbekistan". http: lex.uz/pages/getpege

....

3. Speech by the President of the Republic of Uzbekistan Shavkat Mirziyoyev at a meeting of the Council of Heads of State founders of the International Fund for Saving the Aral Sea, held in the city of Turkmenbashi of Turkmenistan, Narodnoe Slovo 201825 August, No. 173 (7101)

4. Agenda for Sustainable Development until 2030 /I Electronic access: http://www.uz/undp/org/content/uzbekist an.ru

5. Amadaliev Y. Erdan foydalanishni xududiy tashkil ethishning social ecologist husiyatlari. Y̌zbekiston Geography of Zhamiyati akhboroti. Toshkent, 2003.23house. -B. 58-59.

6. Axmadaliev Yu.I. Er resource laridan foydalanish geoecology. $\mathrm{T}$ :: "Fan va tekhnologar" nashriyoti, 2014. -340 b.

7. Abduganiev, O. I., Abdurakhmanov, G. Z. Ecological education for the purposes of sustainable development. The American Journal of Social Science and Education Innovations 2 (08), 2020. // Electronic access:

https://www.usajournalshub.com/index.p hp/tajssei

8. Mirkomil, G., Gulshoda, J., \& llyos, J. (2020). Ways To Develop Ecotourism In The Molguzar Mountains. The American Journal of Applied sciences, 2(11), 1-5.

9. Gudalov, M., \& Imamova, D. (2020). Development of Ecoturism In AydarArnasay Lakes System And Its Surroundings. The American Journal of Applied sciences, 2(10), 150-153.

10. Nazarov, A.Y. (2016). Organization of the use of documents from the Central State 
Archive of Cinema, Photo, Phono Documents of the Republic of Uzbekistan. Document. Archive. History. Modernity. Yekaterinburg, 2016, 484-489.

11. Omonov, Q., \& Karimov, N. (2020). Importance Of Ancestoral Heritage. The American Journal of Social Science and Education Innovations, 2(09), 196-202. 